\title{
Migration crisis and the church: A response to lacunae and considerations for Christian ministry engagement
}

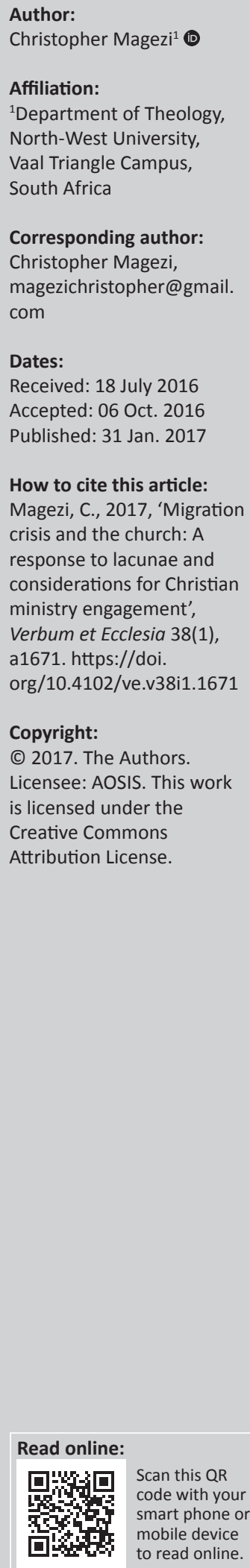

This article critically assesses some theological-ecclesiological responses and approaches to migration challenges in order to ascertain lacunae within Christian ministry engagement. Although other academic disciplines such economics, politics, geography, demography, sociology, psychology, law, history, anthropology and environmental studies shape the discourse of migration, theology boarders the migration debate as if it does not have anything to offer. However, this does not necessarily mean there are no existing theological-ecclesiological responses and approaches to migration challenges. Thus, this article proceeds to categorise the theological-ecclesiological responses to migration challenges into four approaches: (1) the approach that focuses on practical responses from pastoral care that is limited to particular social contexts, (2) the approach of theological motif and ministry praxis from narrow and single biblical texts, (3) the response that focuses on Israel as a paradigm of how the native churches and hosting nations should treat migrants and (4) a systematic approach which focuses on doctrinal formulations that respond to migration challenges. In considering these positions but moving beyond them in response to migration challenges, this article exposes a theological debate and agenda for migration ministry. In doing so, this article identifies some lacunae for further exploration in Christian migration ministry engagement. It concludes by underscoring the need for a meaningful and responsive theology that shapes the discourse of migration, as well as the formulation of operative ecclesiological responses. This article thus contends and paves the way for theological research to become central to migration studies in a manner that demonstrates that theology transcends spiritual reflection to include practical psycho-social, emotional, economic and other dimensions. The contribution of this article lies in its examination of the existing theological-ecclesiological responses and approaches to migration challenges and therefore identifying gaps in theology of migration that can be placed in the theological agenda.

Intradisciplinary and/or interdisciplinary implications: This article outlines theological research agenda for theology and migration ministry. It considers migration theological gaps from a systematic theological and missiological nexus, and as such it is a theological interdisciplinary article integrating systematic and missions. The article contributes to mapping a theological research agenda for the topical issue of migration and refugees in order to develop and inform church ministry designs.

\section{Introduction and background of the study extracted}

The movement of people from their place of 'origin to a destination, or from a place of birth to another destination across international borders' is a severe contemporary issue (Skeldon 2013:2). Likewise, there are also people who migrate from one community or town within the same country (International Organization for Migration [IOM] 2015:35). The earlier movement refers to international migration, whereas the second movement refers to internal migration. This implies that migration has both 'internal and international' features (IOM 2015:35). In other words, international migration is a voluntary or non-voluntary 'movement of people across borders to reside permanently or temporarily in a country other than their country of birth or citizenship' because of political, social, economic, natural disasters or climate change factors ${ }^{1}$ (United Nations Human Rights 2015:17). Every person who migrates from his or her place of birth to another destination across international borders is referred to as a migrant. The foregoing definition of international migrants includes refugees, victims of human trafficking as well as documented or undocumented migrants. In addressing the subject of 'migrants in transit', Gilmore (2016), the deputy High Commissioner for Human Rights, maintains that migrants is an umbrella concept as

1.For extensive discussions of non-voluntary and voluntary causes of migration, one should visit Skeldon (2013:1) and United Nations Human Rights Office of the High Commissioner (2013:7). 
she employs it to represent all people who have a lack of citizenship attached to their hosting countries in common.

IOM (2015) presents a penetrating picture of the extent of international migration as a serious contemporary issue which the international community cannot afford to ignore. It states that:

the number of international migrants worldwide has continued to grow rapidly over the past fifteen years reaching 244 million in 2015 up from 222 million in 2010 and 173 million in 2000. (p. 1)

Likewise, in the Global Challenge of Managing Migration, Martin (2013:2) states that from 1980 to 2010, the number of international migrants has increased by 117 million. In 1980 , the number of international migrants was 103 million, which increased to 220 million by 2010. Furthermore, Martin (2013:2) and the United Nation Department of Economic and Social Affairs (2013) reported that 'the number of international migrants increased from 220 million to 232 million by 2013'. Martin (2013:2) continued to estimate that the number of international migrants is most likely to reach 400 million by 2050. In both confirming and magnifying the extent and gravity of the issue of international migration, the IOM (2014:1) pointedly reported that 'approximately one in seven people are migrating every day'.

Migration confronts both migrants and migrants' hosting nations with various challenges. On the one hand, migrants face discrimination in various forms. Some hosting nations do not recognise the foreign qualifications of migrants which result in migrants accepting low-paying jobs in order to survive in their new homeland. This is usually done by adjusting the human rights of migrants through labour polices which favours the civilians of the hosting nations at the expense of migrants (Bose 2014:23; Datta et al. 2006:8; Kul n.d.). Furthermore, migrants encounter the imposition of burdensome migration regulations (i.e. hosting nations' tightening of their borders and onerous visa requirements) by the hosting nations as a means of discouraging migrants to enter in their country (Chelius 2014:32-33; Gilmore 2016; Rajendra 2014:305; Ridsdel 2014:27-28; Sazonov 2015). On the other hand, the migrants' hosting countries face the following challenges: (1) the cost of resettling and integrating migrants (Boundless 2015; Nie 2015; Thomsen 2016:17), (2) the increment of the rates of unemployment (Rivera-Pagán 2012:575), (3) the dilution of their native cultures (Corhen \& Sirkeci 2011:1; Tan 2012:47), (4) threats from the refugees' opponents (Pakoz 2016) and (5) the suspicion that migrants, particularly refugees, are intertwined with terrorism (Louw 2016:5; Plucinska 2015).

The surfacing problem is that although the existential challenges of both migrants and hosting nations are real and the international community cannot afford to ignore them, theology has been lowly participating in shaping the discourse of migration (Groody 2009a:640; Heimburger 2015:338; Jackson \& Passarelli 2016:46). Nevertheless, this does not necessarily mean that there are no ecclesiologicaltheological responses and approaches to migration challenges.
Although there are ecclesiological-theological responses and approaches to migration challenges, it is apparent that these responses are lacking in numerous ways. Hence, this article seeks to critically assess some theological-ecclesiological responses and approaches to migration challenges in order to identify lacunae for further exploration in Christian ministry engagement. In order to accomplish this objective, the first section will locate migration issues within theological discourse.

In consideration of the state of theological-ecclesiological responses to migration issues, the second section will arguably classify theological-ecclesiological responses to migration challenges into four approaches: (1) the approach that focuses on practical responses from pastoral care that is limited to particular social contexts, (2) the approach that focuses on theological motif and ministry praxis from narrow and single biblical texts, (3) the response that focuses on Israel as a paradigm of how the native churches and hosting nations should treat migrants and (4) a systematic approach which focuses on doctrinal formulations that respond to migration challenges. These theological-ecclesiological responses and approaches to migration challenges will be critically analysed in order to identify their weakness and strengths. Once this is done, the final section will identify some niches from the aforementioned ecclesiologicaltheological responses and approaches to migration challenges that require consideration for further Christian ministry engagement. This article will then conclude by weaving predominant arguments together and aims to provide a clear indication of a theological agenda for migration ministry.

\section{The location of migration issues within theological discourse}

Migration is a serious theological issue because Christianity itself and its foundational doctrines draw significantly from a history that has a clear thread with migration (Theological reflection on migration 2008:4). In this regard, a considerable number of scholars (Campese 2012:22, 2012:4-7; Groody 2009a, 2013:35-38; Rivera-Pagán 2012:575-589) and the church councils (Catholic Church Conferencia Nacional dos Bispos do Brasil 1981:178; the Lausanne Occasional Paper no. 55. 2004) have concurred that both the Old Testament and New Testament clearly assert migration as a biblical concept. These scholars and church councils subscribe to a theological position that states that we are all migrants, starting from Adam to us (cf. Lausanne Occasional Paper no. 55. 2004). It is in Genesis 3 where the original migration of mankind emerged as a result of Adam's rebellion against God and was expelled from the Garden of Eden (Gn 3:1-24). In their expulsion from Eden, Adam and Eve migrated into another land in form of judgement. Thus, in linking Adam's expulsion from Eden as the first migration idea in scripture, scholars are bringing the doctrine of creation and the fall to bear on the biblical notion and philosophy of migration.

However, in reversing the Adamic migration by recreating a new person for himself, God called Abraham to leave his home in order to inherit the promised land of Canaan 
(Gn 12:1-3; Groody 2013:28; Theological reflection on migration 2008:4). This shows us that in God's large salvific purposes, Abraham migrated in form of blessing to dwell in foreign lands which God was to give to him and his descendants (Gn 12). In this way, the notion of Adam and Abraham's migration is juxtaposed. On the one hand, Adam's migration was in form of punishment and destruction, whereas on the other hand, Abraham's migration was particular and universal in nature. The particularity of Abraham's migration was in form of receiving particular blessings for him and his descendants, while the universal aspect of his migration lies in bringing people back to eternal fellowship with God (Torrance 2008:51). This scriptural notion of migration is intensified when Israel, the descendant nation of Abraham, Isaac and Jacob, migrated to Egypt as well as their return to the promised land. This aforementioned migration was a pattern for the entire life of Israel in the Old Testament (Theological reflection on migration 2008:4). Given this:

\begin{abstract}
... the theme of migration is at the heart of the Judeo-Christian scriptures. From the call of Abraham to the exodus from Egypt and Israel's wandering in the desert and later experience of exile, migration has been part of salvation history. (Groody 2009c:1)
\end{abstract}

Likewise, the Catholic Church Conferencia Nacional dos Bispos do Brasil (1981) claims that:

Israel is a country which has been deeply marked by the drama of migrations. Its history has been enriched by this experience and contains important elements which can shed light in the present day reality of migration. (p. 178)

That is, the notion and philosophy of salvation in the Old Testament is 'migration bearing' (Theological reflection on migration 2008:4).

Furthermore, the New Testament speaks about the incarnational mystery of God and Christian life from a migration perspective (Campese 2012:21-23; Matovina \& Tweed 2012:11; Theological Reflection on Migration 2008:4). The former denotes that the migration position of the church is anchored in the mystery of the incarnation in which the infinite, eternal and transcendent God (in and through Jesus Christ) came into our estranged territory in order to save and bring us back to our eschatological homeland in which we will experience full reconciliation between God and us, as well as man and man (Groody 2013:33). Nagy (2015) corresponds with Groody, Matovina and Tweed, and Campese when he affirms that a proper understanding of migration as a metaphorical expression of the incarnational mystery of God will result in one's 'deeper understanding' of the nature of God and his relationship with the world. The latter denotes that the migration position of the church is embedded within the fact that Christians are biblically ascribed as migrants by scriptural texts that describe believers as aliens or strangers in the world (1 Pt 2:11 and Heb 11:1316; Campese 2012:22-23; Groody 2009a:653; Matovina \& Tweed 2012:11; Theological Reflection on Migration 2008:4). Given this, the comprehension of migration as a descriptive metaphor for the incarnational mystery of God and the
Christian life is central in configuring migration as a serious theological concern for the church.

Currently, Aymer (2015:1) understands migration as a theological issue by viewing the New Testament as a diaspora space. She arrived at her conclusion about the New Testament as a diaspora space after a thorough examination of the New Testament books. She argues that the seven unquestionable letters of Paul were written by him when he was in diaspora, instead of his homeland (Aymer 2015:1). The four gospels (Matthew, Mark, Luke and John), Acts and the three epistles of John are mainly identified in the scholarly world as written by some exiled anonymous authors after the siege of Jerusalem by the Roman Empire (Aymer 2015:1). In substantiating her case, she argues that the letters of Hebrews, 1 Peter and James were written within a diaspora space because the authors of these letters identify their audiences as people in exile or aliens. Furthermore, without building a strong case, she simply identifies the letter of Revelation to have been authored by John while in exile (Aymer 2015:1). Therefore, Aymer (2015:1) encapsulates migration as a theological concern for the church because 'the majority of the New Testament authors wrote as migrants (on the road, in exile, on the move) and that their writings constitute sojourners' truths, and thus diaspora space'.

Given the aforementioned discussions, it can be affirmed that both the Old and New Testaments present the notion and philosophy of migration as interconnected with the aspect of God as a migrant and the self-identity of Christians as pilgrims on the way. Thus, Christians are expected to shape the migration debate because the fundamental twin doctrines of Christianity (the incarnation and Christian salvation) rest on the notion and philosophy of migration. However, the arising problem is that although other disciplines such as 'economics, politics, geography, demography, sociology, psychology, law, history, anthropology, and environmental studies' are at the centre of shaping the emerging field of migration studies, theology is at the margin of the migration debate (Groody 2009a:640). Campese (2012:30) and Jackson and Passarelli (2016) observe that theological reflections on migration are immature. Jackson and Passarelli (2016) continue to note that there is very little that has been done to develop migration theology programmes; hence, in-depth theological reflection and programmes should be developed across the spectrum starting with undergraduate programmes. Groody (2009a:639-640) and Heimburger (2015:338) added that theology has been on the periphery of shaping the emerging field of migration as if it does not have anything to offer. The low participation of theology in shaping the emerging field of migration is a serious theological concern because theology and its fundamental doctrines of salvation draws largely from the notion and philosophy of migration (Campese 2012:21-22; Groody 2009c, 2012, 2013; Matovina \& Tweed 2012:11; Nagy 2015; Theological Reflections on Migration 2008:4).

Also, theology and church are intricately linked to society and people's lives. Magezi (2007:176) rightly maintains that 
churches are subsystems of society (communities). In view of these realities, it is imperative for theology to reflect on practical life and societal issues such as migration. Furthermore, churches have been on the forefront in responding to social and community issues. Stark (1996) in his book, The rise of Christianity, clearly illustrates the way how churches have been on the forefront in care ministry. The reality of the church as a community and social institution, its theological content of care, and its tradition and history of care challenges theology to play an active role in migration issues. However, as already noted (Stark 1996), this need does not necessarily mean that there are no theological-ecclesiological responses and approaches to migration. The existing approaches have limitations, hence the need to reflect and improve them. The following section shall present four theological-ecclesiological responses and approaches that have been conveniently developed in this article to categorise theological migration discussions. The fourth category as the dominant category will be discussed in more detail.

\section{Various ecclesiological-theological responses and approaches to migration challenges}

\section{The approach that focuses on practical responses from a pastoral care that is limited to particular social contexts}

Heyer (2012), Snyder (2012), Tan (2012), Adogame (2013) and Matovina and Tweed (2012) are but a few examples of scholars who focus on practical responses from a pastoral care that is limited to a particular social context. Matovina and Tweed focus on Mexican and Cuban exiles; Tan focuses on the Asian context; Adogame focuses on African migrants in diaspora; Snyder focuses on migrants (particularly asylum seekers) in British social contexts and Heyer focuses on Latin American migrants in the United States. The prevalent practical response for many of these scholars is a call for the hosting nations and Christians to accommodate migrants (particularly refugees) as well as standing alongside them as they encounter various challenges. For instance, Heyer (2012) as a representative voice criticised America for its complicit systems that create the conditions which cause many people to engage in unlawful migration. Heyer (2012) further recognises that the complicit systems of America subject Latin American women to sacrifice their sexual purity for survival in the United States. There are many unreported sexual abuse cases involving migrant women in work places because they are scared of being deported.

In bringing the Roman Catholic social teachings and the theological discussion of the analysis of sin to bear on migration challenges, Heyer (2012:50) advances the church as locus for transformation. She calls both the church and the nation of America to employ incarnational and conflictual solidarity as dimensions of solidarity which can save the world troubled with globalisation. The former refers to American churches and America as a nation to identify with many Latino Americans in their various challenges (Heyer 2012:116ff.). The latter calls American churches and America as a nation to fight with conflicting forces which prevents the attainment of incarnational solidarity (Heyer 2012:116ff.). Heyer (2012:160) concludes by bringing the notion and philosophy of migration as a metaphor for Christian pilgrimage at this Christian interim period that 'migrants serve as witness to enduring hope'. In this way, Christians' hospitality towards fellow pilgrims provide 'eschatological glimpses' of the now but not realised Kingdom of God (Heyer 2012:160). In view of the challenges that migrants face, this theological approach represented by Heyer is a useful approach; nonetheless, it is clear that this approach lacks wider application as it focuses on selected contexts.

\section{Theological response and approach to migration crisis that focuses on theological motif and ministry praxis from narrow and single biblical texts}

Snyder (2012) is the representative of the theological response to migration crises which focuses on migration theological motif and ministry praxis from narrow and single biblical texts. Snyder (2012:163-189) calls the churches in Britain, and Britain as a nation, to accept migrants based on the biblical texts of Ruth (a Moabite woman) and the gospel narrative of the Syro-Phoenician woman in Mark 7:25. Snyder (2012) discusses Ruth as a woman who went into a foreign land by faith and was welcomed by Boaz. This resulted in Ruth's inclusion into the foreign nation of Israel (cf. Rt 4:11ff.). In substantiating her point, Snyder (2012) linked Ruth's story to the Syro-Phoenician woman, whom by faith had approached Jesus so that she could heal her child who was tormented by evil spirits (Mk 7:25). In connecting Ruth's plight to those of the Syro-Phoenician woman, Snyder calls migrants to have faith, as well as calling Christians and the citizens of Britain to welcome strangers (Snyder 2012:22, 25, 199). In further underscoring her appeal for the churches in Britain, and Britain, as a nation to be hospitable to migrants, Snyder employs Ruth, by locating the significance of Ruth in the lineage of Abraham which stretches to Jesus, as a classical example on foreigners' contribution in building a foreign nation.

However, the weakness of this approach is that it is both unsystematic and incomprehensive, therefore, unable to make a compelling theological basis for the acceptance of migrants by Christians. In other words, the unsystematic and incomprehensive aspect of Snyder's approach can possibly result in failing to alter the mindset and actions of the targeted audiences. This is because Snyder does not engage with various biblical texts in the New Testament (e.g. Mt 25:31-46; Heb 13:2-3) which provide Christians with a robust theological basis for accepting migrants - particularly strangers (Sagovsky 2014:231). Even though Snyder's theological approach is useful, it is also true that it challenges us to construct a systematic-comprehensive theological approach which draws on the whole council of God's word as a means of establishing a better theological basis for Christians' inclusion of migrants - particularly refugees. 


\section{The approach that focuses on Israel as a paradigm of how native Christians and hosting nations should treat migrants}

In response to the migration crisis, Matovina and Tweed (2012:9), Rivera-Pagán (2012:580-584) and Heinrich BedfordStrohm (2008:40) are using an approach that focuses on Israel as a paradigm of how native Christians and hosting nations should treat migrants. That is, Israel as a covenantal nation of God is taken as an example of how local communities and the churches of the hosting nations should treat migrants in their homeland. In taking Israel as a model of churches and nations' response to migrants, these scholars perceive God's command for Israel to love the foreigners in their land as a dominating response which the church and hosting nations have to exhibit in the current migration crisis (BedfordStrohm 2008:40-41). This understanding is rooted in the experience of the salvific history of the nation of Israel (Bedford-Strohm 2008:40-41). Israel has experienced the pain of being a stranger in its captivity in Egypt, and therefore, it was supposed to treat foreigners in the way it would have wanted to be treated herself (Lv 19:33-34; cf. Dt 10:19-20, Ex 22:20, 23:9, cf. Matovina \& Tweed 2012:9; Bedford-Strohm 2008:40-41).

Bedford-Strohm (2008:40-41) emphasises that the Israelite community was commanded to love strangers among them in the same way they love themselves (cf. Lv 19:33-34). In saying this, Bedford-Strohm (2008) is moving towards his affirmation that the churches and nations are to act likewise as a means of ending discrimination, xenophobia and the exploitation of migrants. That is, just like Israel, God commands equality between migrants and the citizens of the hosting nations; therefore, migrants' hosting communities and native churches are to act in a reciprocal manner. In developing an ethics of empathy, Bedford-Strohm (2008) demonstrates how the commandment of Leviticus 19:33-34 is promoted by God in the subsequent comprehensive summary:

Firstly, the commandment is emphasized as comprehensible and accessible from Israel's own experience: 'You know how it feels to be foreign and discriminated against. Therefore treat the foreigner just like you would want to be treated if you were in the same situation!' Secondly, the reasoning for the commandment culminates by referring to God Himself: 'I am the Lord your God'. I adopt the cause of all foreigners just like I. (p. 41)

Bedford-Strohm (2008:40-41), Matovina and Tweed (2012:9) and Rivera-Pagán (2012:580-584) represent theology in a way which recognises the teachings of the Old Testament about how Israel is to relate to strangers or foreigners among them. It is agreed that Israel was commanded by God to love the strangers among them as they love themselves. However, a point of contention, concerning the current nations experiencing migration crises, is that there is a tendency to directly apply Israel's manner of dealing with the foreigners. This is problematic because Israel was a theocratic and covenantal nation of God, which is distinct to any other nation. Israel was a distinct nation and has a particular relationship with God. For instance, it was a priestly nation chosen by God as his instrument of salvation to the whole world. This clear distinction begs for bridges in bringing Israel as a model of response for non-theocratic nations encountering migration challenges at the moment.

\section{Systematic theological approach that focuses on doctrinal formulation that responds to migration crisis}

Campese (2012), Hilkert (1995), Groody (2008, 2009a, 2009b, 2009c, 2010, 2012, 2013, 2015), Bedford-Strohm (2008), RiveraPagán (2012) and Aymer (2015:1) are scholars who employ a systematic approach to migration challenges that focus on doctrinal formulations. This approach is championed by Groody (2009a:639-641) who provides a comprehensive treaty on migration from a doctrinal-theological point of view. As a representative voice of this category, Groody (2009a:649-643) views the twin doctrines of the incarnation and reconciliation as the central basis for Christians' acceptance of migrants or foreigners. Groody (2009a:649) asserts the centrality of the doctrine of incarnation in the discussion of migration as he argues that 'no aspect of a theology of migration is more fundamental, nor more challenging in its implications, than the incarnation'. In saying this, Groody is moving towards the interconnection of the doctrine of incarnation and reconciliation as he understands that all mankind were once alienated, separated and far away from God because of sin (cf. Rm 5:1-11; Col 1:21ff.). Thus, in the incarnation, in and through Christ, the gracious and loving God migrated from his eternaltranscendent place of dwelling to our foreign territory to identify with us in order to destroy the dividing barriers which existed between God and us, as well as man and man through Christ's redemptive acts (Eph 2:11-22; Groody 2009a:649-642). In this way, the incarnation provides us with the notion that the eternal God in Christ came into a foreign territory of estranged humanity as a means of redefining the 'borders between neighbours and opens up the possibility for new relationships' (Groody 2009a:652). Furthermore, the incarnation confronts Christians (those reconciled with God through faith in the redemptive acts of Christ) with a new 'framework for evaluating human migration and questions some of the underlying premises of the debate' (Groody 2009a:652).

In substantiating his appeal for Christians to embrace migrants, Groody (2009a:653) calls the church to view migration issues from the perspective of God's Kingdom and the mission of the church. The vision of the Kingdom of God has to shape the identity of believers in this world. In other words, the vision of the Kingdom of God and the mission of the church are intrinsic in God's mission of reconciling the world to himself, through Christians as the agency of that ministry of reconciliation (Groody 2009a:653). The Kingdom of God was inaugurated at the incarnational mystery of God in and through Jesus Christ (Groody 2009a:653). In both deeds and actions, Jesus demonstrated the nature, character and mission of God's Kingdom (Groody 2009a:653). The nature, 
character and mission of the Kingdom of God as demonstrated by Jesus Christ is marked by love and compassion, that is, Jesus Christ exemplified the acceptance of the strangers and marginalised in the Kingdom of God by 'reaching out to the Syro-phoenician or Canaanite woman (Mt 15:21-28; Mk 7:2430) as well as his response to the Roman centurion (Mt 8:513; Lk 7:1-10)' (Groody 2009a:653).

However, even though the Kingdom of God should be viewed by the church within its eschatological sense, it is also correct that the eschatological Kingdom of God has invaded the present, and through the power of the Spirit, the Church of Christ is called to act as the agency of the advancement of the Kingdom of God to people of all tongues, tribes and nations (Mt 28:16-20; Groody 2009a: 650-667; cf. Catholic Church Conferencia Nacional dos Bispos do Brasil 1981:180-181; Rodewald 2014:60-61). In this way, Groody (2009a:638) concludes that migration 'is a way of thinking about God and human life and an expression of the Christian mission of reconciliation'. The above discussion suggests that Groody is a representative of systematic approaches that provide sound theological motivation by formulating Christian dogmas which locate the basis for Christians' commitment to migration issues, as well as the basis for Christians' reception of strangers. Nevertheless, it is apparent that his sound theology does not result in constructing ministerial and ecclesiological models which respond to the challenges of migrants. The question which Groody and all other theologians in this category are not answering is about the practical linkage between their doctrinal constructions with the real social needs of migrants. Doctrine is about life, so it has to empower people to live and practically cope with life in their various contexts. That is, Christian dogmas as a theological enterprise should be 'life science' (Louw 2014:11), which means that doctrine should be practical in nature (Campese 2012:6; Cruz 2010:121; Fowler 1983:154-155; Louw 2014:11).

To further delineate this systematic theological approach, the primary interpretation of migrants as the image bearers of God is one of the dominant views that should be considered in substantial detail. Rivera-Pagán² (2012:586), Groody (2009a:642) and Zetter (1991:40) think that the political labels which are named after migrants by the hosting nations also contribute towards their discrimination by the local communities. In response to the language problem as one of the causes for the discrimination of migrants, Hilkert (1995:190-204) and Groody (2009a:642) bring the doctrine of creation to bear on the matter. They argue that human beings are created in the image of God (Imago Dei) (cf. Gn 1:26-27; 5:1-3; 9:6; 1 Cor 11:7; Ja 3:9). This should be our primary basis in perceiving migrants (Hilkert 1995:190-204; Groody

2.Rivera-Pagan (2012:586) argues that migrants are to be fully recognised as the image bearers of God '... both in the letter of the law and in the spirit of social image bearers of God
praxis'. He adds that:

whatever the importance of the economic factors for the receiving nation (which usually, as in the case of the United States, happens to be an extremely be the existentia we the be the existential wellbeing of the 'least of these', of the most vulnerable and marginalized members of God's humanity, among them those who sojourn fa away from their homeland, constantly scrutinized by the demeaning gaze of many native citizen. (p. 586) 2009a:642). In saying this, they urge hosting nations to perceive migrants as, first and foremost, people created in the image of God. This is a central doctrine which emerges from the early pages of scripture. The interpretation of migrants by their political status or categories (such as legal, illegal, undocumented and alien) is a complete denial of the migrants' identity which is rooted in the image of God (Groody 2009a:642; Rivera-Pagán 2012:586). Even though Zetter (1991:40) wrote before Groody, Rivera-Pagán and Hilkert, he concurs with them in his affirmation that ' ... far from clarifying an identity, the label conveys, instead, an extremely complex set of values, and judgments which are more than just definitional'. Here, the problem is that perceiving migrants in political terms will make them susceptible and, therefore, exposes them to exploitations by the local communities and employers of the hosting nations.

In other words, Groody (2009a) is of the opinion that the perception of migrants as primarily '... lawbreakers, aliens or criminals' is dangerous because it will make the sufferings of migrants have no claim to the hosting nations or local communities. In this way, the hosting nations 'can rest content' on their side 'of the dividing wall' because they convince themselves that the migrants are 'excluded for a reason' (Groody 2009a). This treatment will definitely expose migrants into an inescapable 'psychological colonisation' they have to live within their new homeland (Groody 2009a:642). In signifying this, Groody hopes that if the local communities and the authorities of the hosting nations perceive migrants as people created in the image of God, they are going to treat migrants with their God-given identity. This understanding will shape the migration debate, particularly the international formulation of migration policies, in a positive way (Groody 2009a:644). In this way, Groody, Hilkert and Rivera-Pagán are reinforcing the doctrine of the Imago Dei as the primary symbol that should function as the hosting nations' (local communities) primary interpretation of migrants. The use of the Imago Dei as the primary symbol in perceiving migrants is crucial in making the native communities of the hosting nations to cease their exploitation and racial discrimination of migrants. This is because the local communities of the hosting nations will primarily perceive migrants as important people of equal status (whose identity and dignity is rooted in God) with themselves before God.

However, although Hilkert, Rivera-Pagán and Groody state a plausible response to the challenges of migrants, it is apparent that they seem to disregard the fact that these hosting nations are not theocratic nations which take scripture as the inspiredauthoritative word of God, which governs all aspects of their lives. For instance, the way we relate to one another or perceive each other as human beings created in the image of God. In failing to pay attention to the foregoing, Hilkert, Rivera-Pagán and Groody's doctrinal response is most likely to remain as an abstract doctrinal formulation which does not have practical contribution to economic, political and social existential challenges of migrants. This is because even though their response is theologically sound, it is also true 
that they did not construct some points of negotiations which enable them to bridge the Christian doctrine of the Imago Dei as an operative framework which governs the hosting nations' primary interpretation of the value of migrants.

\section{The existing theological- ecclesiological lacunae for further exploration in Christian ministry engagement to migration}

The preceding section confronts us with four useful theological-ecclesiological responses and approaches to migration crises which are also deficient in various ways. The first theological response and approach focuses on single contexts in drawing migration application principles. Snyder (2012), Heyer (2012), Tan (2012), Adogame (2013) and Matovina and Tweed (2012) are some of the reputable scholars who employ theological responses and approaches that focus on single contexts in drawing migration application principles. The limitation of this theological response and approach lies in its failure to have application to a wider context.

The second theological response to migration crises is the approach that focuses on theological motif and ministry praxis from narrow and single biblical texts. Snyder (2012) is an appropriate representative of this category. The problem with this approach is that it lacks a comprehensive theological reflection on the subject of migration. This is because single context application and single text approaches weaken broader application to theological principles, are incomprehensive and are arguably unsystematic ${ }^{3}$ in treatment of doctrine hence insufficient.

The third theological response to migration crises is the approach that focuses on Israel as a paradigm of how native churches or Christians of the hosting nations, and the hosting nations themselves, should treat migrants. This approach has a tendency of making a direct application of Israel's dealing with the foreigners as a response which the current nations experiencing migration crisis have to emulate. This is problematic because Israel is both a theocratic and covenantal nation of God, which is distinct to any other nation. Israel was a distinct nation and has a particular relationship with God. For instance, it was a priestly nation chosen by God as his instrument of salvation to the whole world. This clear distinction between the scriptural nation of Israel and the contemporary nations begs for bridges in bringing Israel as a model of response for non-theocratic nations encountering migration challenges in the contemporary world.

The final theological response is a systematic theological approach that focuses on doctrinal formulation that responds to migration crises. Campese (2012), Groody (2009a, 2009, 2012, 2013), Bedford-Strohm (2008), Rivera-Pagán (2012) and Aymer (2015) are some of the estimable scholars who utilise a

3.Unsystematic does not refer to systematic theology but rather broadness in treatment of a subject. systematic theological approach that focuses on doctrinal formulation in response to migration crises. The problem with this approach lies in its failure to proceed in constructing ministerial and ecclesiological models that respond to the existential challenges of migrants. In this way, this theological approach fails to explicitly draw links between reflection and praxis. By failing to draw explicit links between doctrine and praxis, this approach can be blamed for assuming that doctrinal formulations automatically translate to practice. This is because it focuses on reflection and doctrinal formulation and fails to outline the implication of such doctrine to practical life to ensure that theology becomes a life science (Campese 2012:6; Cruz 2010:121; Fowler 1983: 154-155; Louw 2014:11).

Given this, the above theological responses to the challenge of migration crises are theologically limited in various ways. Viewed from a missiological and practical theological perspective, these approaches weaken theology's relevance to broad practical life issues such as migration. At worst, it renders theology as idealistic and impractical. Van Engen (2004:50) counsels that from a Theology of Missions perspective, theology should take the biblical text with complete seriousness. This thorough consideration of the biblical text should result in Theology of Missions' practical participation in the world in response to the contemporary challenges in which God's mission occurs. This central aspect of missional theology converges with the entire enterprise of practical theology. Likewise, Dakin (1996:203) sharply sustains that 'practical theology must not only address the levels of reflection but also provide a perspective and an orientation for the knowledge with which it is concerned'. Louw (2014:11) added that doctrinal formulations must have clear and relevant implications to the existential challenges of people. Hendriks (2007:999) explains that missional theology and ecclesiology focuses on a contextual praxis, which necessitates a reflective engagement of faith communities in the world. The methodology entails fusing and integrating who God and what his word (scriptures) is in this world, the church, the mission and responsive practical actions.

In view of the above, Cruz (2010:121) recommends that theology should dialogue with the current challenges that migrants encounter. Reactive ministerial and ecclesiological models that respond to the challenges of migrants should be developed. Hence, in advancing a useful intercultural theology of migration, Cruz (2010:121, cf. Bosch 1991:4944) poignantly points out that 'Indeed, all theology participates in his/her story (God, my emphasis) to address the issue of the day or the signs of the times'. Theology has to dialogue with current forms of arising issues. An emerging problem indicates that while theology is expected to dialogue with migration, scholars observe that theology has been peripherally participating in shaping the discourse and responses to migration crises. Notably, other disciplines such

4.In Transforming Mission: Paradigm Shifts in Theology of Mission, Bosch (1991) asserts that:

we are in need of a missiological agenda for theology rather than just a theological agenda for mission; for theology, rightly understood, has no reason to exist other than critically to accompany the Missio De. (p. 494) 
as 'economics, politics, geography, demography, sociology, psychology, law, history, anthropology, and environmental studies' (Groody a 2009:640) are at the centre in shaping the emerging field of migration studies while theology is on the side-lines. This lacuna is indeed of theological concern.

The above-mentioned lacunae indicate a challenge to place theological reflection of migration on the theological agenda. The World Team International (2011:6-7), which is a global missions think tank of researchers, in their global overview and trend mapping on modern missions observed that migration is one of the major global developments that will impact global mission. They state that migration is a central global issue of the 21st century that is shaping the current and will continue to shape the future church and its mission. This arises from the fact that migration is not static. The number of people moving across international borders is rapidly increasing every year as highlighted by statistical data on migration (Campese 2012:5-6; World Team International 2011:6). Thus, the challenge of migration requires the church to rethink its mission in the globalised world where migration is a key reality. Mission is no longer going 'out there' but 'here' (World Team International 2011:6-7).

Notably, therefore, the lacuna indicated above leads one to observe that a meaningful responsive theology that shapes the debate of migration, as well as informing ecclesiologicalpractical responses is at stake. In this respect, theology is not simply expected to be involved in the migration debate but it has to contribute to the migration debate. This is why Groody (2009) correctly avows that:

the current climate points to the need to move the migration debate to an even broader intellectual terrain, one in which theology not only has something to learn but something to offer. (p. 641)

This is because the contribution of theology transcends spiritual reflection to include practical psycho-social, emotional, economic and other dimensions. This enterprise aims at locating theology at the centre stage of migration dialogues as well as exploring ecclesiological-practical responses to the problem to which theology is currently lowly involved and in some instances completely uninvolved.

\section{Conclusion}

The purpose of this article was to critically assess some theological-ecclesiological approaches and responses to migration challenges in order to identify lacunae for further exploration in Christian ministry engagement. The article critically assessed the various theological-ecclesiological responses and approaches. It revealed that some scholars are of the opinion that although other disciplines are at the centre stage in shaping the emerging field of migration, theology is at the periphery. From the theological conversations on migration, there are two predominant lacunae that have been observed that should be considered for further Christian ministry engagement in response to migration crises. Firstly, there is the need for theological researches to develop a legitimate biblical and theological position on migration that shapes the discourse. Directly emerging from the first need is the second one, namely the need for an operative ecclesiology that is both missional and practical in nature to ensure development of holistic ministries. These two challenges arguably provide a useful agenda across contexts for meaningful migration ministries. In doing so, theology will claim and strengthen its place at the 'table' of contributing to migration response at spiritual and social dimension levels.

\section{Acknowledgements Competing interests}

The author declares that he has no financial or personal relationships which may have inappropriately influenced him in writing this article.

\section{References}

Adogame, A., 2013, The African Christian diaspora: New currents and emerging trends in world Christianity, Bloomsbury, London.

Aymer, M.P., 2015, 'Sojourners truths - The New Testament as diaspora space', The Journal of the Interdenominational Theological Centre 41, 1-18.

Bedford-Strohm, H., 2008, 'Responding to the challenges of migration and flight from a perspective of theological ethics', in Theological reflections on migration, A Churches Commission for Migrants in Europe Reader, Brussels, viewed 20 May 2016, from http://www.ccme.be/fileadmin/filer/ccme/01 WHO WE ARE/2008 CCME_Reader-_Theological_Reflections_on_Migration.pdf

Bosch, D.J., 1991, Transforming mission: Paradigm shifts in theology of mission, Orbis Books, Maryknoll, NY.

Bose, S., 2014, 'Illegal migration in the Indian Sunderbans', in Forced migration review, Issue 45, viewed 30 March 2016, from http://connection.ebscohost.com/c/ articles/94903338/illegal-migration-indian-sunderbans

Boundless, 2015, 'Impact of immigration on the host and home country economies' Boundless Economics, viewed 18 May 2016, from https://www.boundless.com/ economics/textbooks/boundless-economicstextbook/immigration-economics-38/ introduction-to-immigration-economics-138/impact-of-immigration-on-the-hostand-home-country-economies-546-12643/

Campese, G., 2012, 'The irruption of migrants: Theology of migration in the 21s century', Theological Studies 73(1), 3-32. https://doi.org/10.1177/004056 391207300101

Catholic Church Conferencia Nacional dos Bispos do Brasil, 1981, 'Where are you going: Theological reflections on migration', Ecumenical Review 33(2), 178-185. https://doi.org/10.1111/j.1758-6623.1981.tb03304.x

Chelius, L.C., 2014, 'Mexicans seeking political asylum', viewed 28 May 2016, from http://www.fmreview.org/crisis/calderon.html

Corhen, J.H. \& Sirkerci, I., 2011, Cultures of migration: The global nature of contemporary mobility, University of Texas Press, Austin, TX.

Cruz, G.T., 2010, An intercultural theology of migration: Pilgrims in the wilderness, Brill, Leiden.

Dakin, K., 1996, 'The nature of practical theology repeating transformation: Browning and Barth on practical theology', Anvil 13(3), 203-221.

Datta, K., Mcllwaine, C., Evans, Y., Herbert, J., May, J. \& Wills, J., 2006, Work and survival strategies among low-paid migrants in London Department of Geography Queen Mary, University of London, London, viewed 20 May 2016, from http:// www.geog.qmul.ac.uk/globalcities/wpaper3.pdf

Fowler, J.W., 1983, 'Practical theology and the shaping of Christian lives', in D.S. Browning (ed.), Pastoral theology: The emerging field in theology, church and world, pp. 148-166, Harper \& Row, San Francisco, CA

Gilmore, K., 2016, 'Keynote address: Side event migrants in transit by Deputy High Commissioner for human rights', viewed 20 May 2016, from http://www.ohchr. org

Groody, D.G., 2008, 'On the human face of the migrant', Missio Apostolica 16(1), 67-69.

Groody, D.G., 2009a, 'Crossing the divide: Foundations of a theology of migration and refugees', Theological Studies 70(3), 638-667. https://doi.org/10.1177/0040563 90907000306

Groody, D.G., 2009b, 'Jesus and the undocumented immigrant: A spiritual geography of a crucified people', Theological Studies 70(2), 298-316. https://doi. org/10.1177/004056390907000204

Groody, D.G., 2009c, 'Crossing the divide: Foundations of a theology of migration and refugees', Theological Studies 70, viewed 28 March 2016, from http://ncronline. org/news/global/theology

Groody, D.G., 2010, Crossing the divide: Foundations of a theology of migration and refugees, Church Mission Society, Oxford. 
Groody, D.G., 2012, 'Homeward bound: A theology of migration for fullness of life, justice and peace', The Ecumenical Review 64(3), 299-313. https://doi. justice and peace', The Ecumenical
org/10.1111/j.1758-6623.2012.00175.x

Groody, D.G., 2013, 'The Church on the move: Mission in age of migration', Mission Studies 30(1), 27-42. https://doi.org/10.1163/15733831-12341256

Groody, D.G., 2015, 'Passing over: Migration as conversion', International Review of mission 104(400), 46-60. https://doi.org/10.1111/irom.12075

Hendriks, J.H., 2004, Studying Congregations in Africa, Lux Verbi, Wellington, BM.

Heimburger, R.W., 2015, 'Fear and faith in the kin-dom: New explorations in the theology of migration', Modern Theology 31(2), 338-344. https://doi.org/10.1111/ moth. 12150

Heyer, K.E., 2012, Kinship across borders: A Christian ethic of immigration, Georgetown University Press, Washington, DC.

Hendriks, J.H., 2007, 'Missional theology and social development', HTS 63(3), 999-1016. https://doi.org/10.4102/hts.v63i3.244

Hilkert, M.C., 1995, 'Cry beloved image: Rethinking the image of God', in A.O. Graff (ed.), The embrace of God: Feminist approaches to theological anthropology, pp. 190-204, Orbis, Maryknoll, NY.

International Organization for Migration (IOM), 2014, Global migration trends: An overview, viewed 28 May 2016, from http://missingmigrants.iom.int/sites/ default/files/documents/Global_Migration_Trends_PDF_FinalVH_with $\% 20$ References.pdf

International Organization for Migration (IOM), 2015, World migration report 2015 viewed 23 May 2016, from http://www.un.org/en/.../migration/.../ migrationreport/.../MigrationReport2015_Highlights.p

Jackson, D. \& Passarelli, A., 2016, Mapping migration, mapping churches' responses in Europe, viewed 23 May 2016, from http://www.ccme.be/.../2016-01-08 Europe, viewed 23 May 2016, from http://w
Mapping_Migration_2015_Online_lo-res____.pdf

Kul, Y., n.d., Opportunities and challenges of international migration for sending and receiving countries, viewed 04 June 2016, from http://www.mfa.gov.tr/ opportunuties-and-challenges-of-international-migration-for-sending

Lausanne Occasional Paper, no. 55, 2004, The new people next door, viewed 20 May 2016, from http://www.lausanne.org

Louw, D.J., 2014, Wholeness in hope care on nurturing the beauty of the human soul in spiritual healing, LIT, Wien.

Louw, D.J., 2016, Between xenophobia and xenodochia in an operative ecclesiology of home: The plight of refugees and migrants as challenge to a diagnostic approach in a pastoral hermeneutics of caregiving, Unpublished.

Magezi, V., 2007, HIV and AIDS, poverty and pastoral care \& counselling: A homebased and congregational systems ministerial approach in Africa, Sun Media, Stellenbosch.

Martin, P., 2013, 'The global challenge of managing migration', Population Bulletin 68(2), 1-15, viewed 23 April 2016, from http://www.prb.org/pdf13/globalmigration.pdf

Matovina, T. \& Tweed, T., 2012, 'Migration matters: Perspectives from theology and religions studies', Apuntes 32(1), 4-20.

Nagy, D., 2015, 'Minding methodologies: Theology - Missiology and migration studies', Mission Studies 32(2), 203-233. https://doi.org/10.1163/15733831 12341401

Nie, Z., 2015, The global edge: The effects on host countries. File under: Europe, Germany Syria, Economy, viewed 23 May 2016, from globaledge.msu.edu > Get Connected , globalEDGE Blog

Pakoz, Z., 2016, 'Refugee haven under attack', Mail and Guardian, 20-26 May.

Plucinska, J., 2015, The Paris attack have put Europe's refugee crisis under renewed scrutiny, viewed 27 May 2016, from time.com/4114009/paris-attacks-migrantcrisis-refugees-eu/
Rajendra, T.M., 2014, 'Justice and benevolence: Catholic social thought, migration theory, and the rights of migrants', Political Theology 15(4), 290-306. https://doi. org/10.1179/1462317X13Z.0000000007
theory, and the rights of migrants', Political

Ridsdel, J., 2014, 'Adolescence, food crisis and migration', Forced Migration Review 45, 27-28, viewed 02 April 2016, from https://www.files.ethz.ch/isn/176966/ crisisNo45.pdf

Rivera-Pagán, L.N., 2012, 'Xenophilia or xenophobia: Towards a theology of migration', The Ecumenical Review 64(4), 575-589. https://doi.org/10.1111/erev.12013

Rodewald, H.R., 2014, 'Barriers to the gospel: Approaching contextualisation from a confessional Lutheran perspective', Missio Apostolica 22(1), 54-62.

Sagovsky, N., 2014, 'Asylum seeking, migration and church by S. Snyder', Book Review in Journal of Anglican Studies 12(2), 229-231.

Sazonov, A., 2015, 'Paris attack and Europe's response to the refugee crisis', viewed 17 April 2016, from http://www.huffingtonpost.com/european.../paris-attacks17 April 2016, from http://w
and-europes_b_8684636.html

Skeldon, R., 2013, 'Global migration: Demographic aspects and its relevance for development technical paper', No. 2013/6, in United Nations Department of Economic and Social Affairs, viewed 27 March 2016, from http://www.un.org/ esa/population/migration/documents/EGM.Skeldon_17.12.2013.pdf

Snyder, S., 2012, Asylum-seeking, migration, and Church, Ashgate, Farnham.

Stark, R., 1996, The rise of Christianity: How the obscure, Marginal Jesus movement became the dominant religious force in the Western world in a few centuries, Princeton University Press, Princeton, NJ.

Tan, J.Y., 2012, 'Migration in Asian and its missiological implications: Insights from the migration theology of the federations of Asian bishops' conference (FABC)', Mission Studies 29(1), 45-61. https://dx.doi.org/10.1163/157338312X638019

Theological Reflections on Migration, 2008, 'A Churches commission for migrants in Europe reader', Brussels, viewed 20 May 2016, from http://www.ccme.be/ fileadmin/filer/ccme/01_WHO_WE_ARE/2008_CCME_Reader-_Theological Reflections_on_Migration.pdf

Thomsen, P.M., 2016, 'The refugee surge in Europe: Economic challenges', viewed 28 May 2016, from https://www.imf.org/external/pubs/ft/sdn/2016/sdn1602. $28 \mathrm{M}$
$\mathrm{pdf}$

Torrance, T.F., 2008, Incarnation: The person and life of Christ, IVP, Downers Grove, IL.

United Nations, Department of Economic and Social Affairs, Population Division, 2013, World migration in figures, a joint contribution by UN-DESA and the OECD to the United Nations high-level dialogue on migration and development, October 03-04, 2013, viewed 28 May 2016, from https://www.oecd.org/els/mig/WorldMigration-in-Figures.pd

United Nations Human Rights, Migration, human rights and governance, Hand Book for parliamentarians no 24, 2015, Published by Inter-Parliamentary Union 2015 , viewed 02 April 2016, from http://www.ipu.org/PDF/publications/migrationen.pdf

United Nations Human Rights Office of the High Commissioner, 2013, Migration and human rights: Improving human rights-based governance of international migration, viewed 12 May 2016, from http://www.ohchr.org

Universal Declaration of Human Rights, 1948, Fact Sheet No.2 (Rev.1), The International Bill of Human Rights, viewed 27 May 2015, from http://www.ohchr. org/Documents/Publications/FactSheet2Rev.1en.pdf

Van Engen, C.E., 2004, 'What is theology of mission', Teologíay Cultura 1(1), 1-10.

World Team International, 2011, Global quick view: Trends and issues that will likely impact the mission of world team in future years (2011-2020), viewed 02 June
2016 , from global.worldteam.org/data/sites/16/Resources/global-quickview2016, from gune-2011b1.pdf

Zetter, R., 1991, 'Labelling refugees: The forming and transforming of a bureaucratic identity', Journal of Refugee Studies 4, 39-62. https://doi.org/10.1093/ jrs/4.1.39 